\title{
Gross Anatomy of the Stomach of the Dorcas Gazelle (Gazella Dorcas, Linnaeus, 1758)
}

\author{
Anatomía Macroscópica del Estómago de la Gacela Dorcas (Gazella Dorcas, Linnaeus, 1758)
}

\author{
Hassen Jerbi*; Mohamed Bayoudh**; Marcus Clauss ${ }^{* * * *} \&$ William Pérez ${ }^{* * * * *}$
}

JERBI, H.; BAYOUDH, M.; CLAUSS, M. \& PÉREZ, W. Gross anatomy of the stomach of the dorcas gazelle (Gazella dorcas, Linnaeus, 1758). Int. J. Morphol., 34(4):1266-1270, 2016.

SUMMARY: The macroscopic anatomy of the stomach in four adult dorcas gazelle was described. Four adult, two male and two female dorcas gazelle (Gazella dorcas) of the Frigya Zoological Park, Enfidha, Tunisie, were used in this study. The ruminal papillae were distributed unequally in the rumen, and were larger and more abundant within the atrium and in the two saccus cecus. The papillae were absent in dorsal part of the dorsal sac. The ruminal pillars had no papillae. The cellulae reticuli were divided and contained secondary and tertiary crests. The curvatura omasi measured $12.1 \pm 0.1 \mathrm{~cm}$. A comparison with literature data for sand gazelles (Gazella subgutturosa marica) emphasises that differences between closely related species that fill similar niches cannot be expected to follow a clear pattern, but yield an inhomogenous picture, with some measurements more tending towards a specific feeding type in the one, and some other measurements tending more towards that feeding type in the other species. We concluded that the stomach morphology of the dorcas gazelle indicates the 'cattle-type' morphophysiology representative for intermediate feeders.

KEY WORDS: Abomasum; Abdomen; Antelope; Forestomach; Proventriculus.

\section{INTRODUCTION}

The actual knowledge of the digestive anatomy of non-domestic ruminants is based on a variety of comparative (e.g. Hofmann, 1973; Langer, 1973; Hofmann, 1988) and species-specific studies (e.g. Hofmann et al., 1995; Pérez et al., 2015; Sauer et al., 2016a), but to date the anatomy of many ruminant species has not yet been described. According to their feeding type, ruminants are classified into three groups (browsers, intermediate feeders, grazers) (Hofmann \& Stewart, 1972; Hofmann, 1973; Hofmann, 1989). Some authors proposed a new classification of ruminants based on digestive morphophysiology only types: species of 'cattletype' or 'moose-type' physiology (Clauss et al., 2010a; Dittmann et al., 2015). Strict browsers or 'moose-type' ruminants have homogenous rumen contents, thin rumen pillars, low reticular crests and a small omasum; in contrast 'cattle-type' ruminants have stratified rumen contents, thick rumen pillars, high reticular crests with deep cells and a large omasum (Clauss et al., 2006; Clauss et al., 2009; Clauss et al., 2010b). 'Cattle-type' ruminants include varying amounts of grass in their diet and may be both strict grazers or mixed feeders (Codron \& Clauss, 2010).

Gazelles belong to the subfamily Antilopinae of the Bovidae family. The dorcas gazelle (Gazella dorcas) is one of the smallest species of Gazella with six recognized subspecies (Groves, 1981). Dorcas gazelle range across Algeria, Burkina Faso, Chad, Djibouti; Egypt, Eritrea, Ethiopia, Israel, Jordan, Libya, Mali, Mauritania, Morocco, Niger, Somalia, Sudan, Syrian Arab Republic, Tunisia, and Yemen. Dorcas gazelle inhabit a wide range of arid and semiarid habitats, but avoid extensive areas of dunes and hyperarid areas (Cuzin, 2003; Lafontaine et al., 2006).

The Dorcas gazelle was listed as vulnerable in the IUCN red list (IUCN, 2008). The dorcas gazelle is an endangered mammalian species in North Africa and their numbers have been drastically reduced during recent years due to overhunting and habitat loss. Consequently, only a

\footnotetext{
* Service d'Anatomie, Ecole Véterinaire Sidi Thabet. CP 2020, Tunisie.

** Zoological Park : Frigya parc, Enfidha, Tunisie. http://www.friguiapark.com/

**** Clinic for Zoo Animals, Exotic Pets and Wildlife, Vetsuisse Faculty, University of Zurich, Zurich Switzerland.

***** Área de Anatomía, Facultad de Veterinaria, Lasplaces 1620, 11600 Montevideo, Uruguay.
} 
few small and scattered populations remain in the wild (Godinho et al., 2012).

Dorcas gazelles are well adapted to the harsh climate of the desert (Yom-Tov et al., 1995). They withstood lack of free water for 9 - 12 days in winter and for 3 - 4 days in summer. Gazelles must drink even in winter if fed on dry food only (Ghobrial, 1976). If animals feed on Acacia leaves, the plants cover the water requirements during winter, but not during summer (Ghobrial, 1974). In Israel, Dorcas gazelles live in areas where no free water is available, and in these areas, the gazelles probably maintain their water balance by behavioral adaptations like feeding early in the morning and by feeding green leaves of Acacia (Yom-Tov et al.).

Dorcas gazelles feed on the flowers, leaves, and pods of Acacia trees in many of the areas they inhabit and they also feed on fruits and leaves of a variety of bushes (Ward \& Saltz, 1994; Yom-Tov et al.).

To our knowledge, there is no available information on the macroscopic anatomy of the stomach of the dorcas gazelle, so the objective of this article was to describe the stomach of dorcas gazelle of Tunisia, North Africa.

\section{MATERIAL AND METHOD}

Four adult, two male and two female dorcas gazelle (Gazella dorcas) of the Frigya Zoological Park, Enfidha, Tunisia,were used in this study. The park keeps antelopes, giraffes and other animals in an open space of 20 hectares with grass, acacias trees and water holes. Animals grazed pastures mostly composed of Stipa tenacissima and each day received supplemental carrots, apples and hay.

The age of the animals ranged between 2.5 and 4 years. The body condition was excellent and the body weight was $15 \pm 2.5 \mathrm{~kg}$. The cause of the death was unknown but not related to digestive system, and the animals were dissected immediately after being found dead. The specimens were handled and treated according to the local Ethical Board guidelines of Ecole Véterinaire Sidi Thabet of Tunisia. The ventral abdominal wall was removed. The stomach was removed after sectioning the oesophagus just prior to the diaphragm and the pylorus just before the duodenum. Stomach contents were measured by weighing the unopened organ and re-weighing it after it had been opened, contents rinsed with tap water, and the organ dried with paper towels. Anatomical measurements were taken following standard procedures (e.g. Hofmann et al.; Pérez
\& Ungerfeld, 2012; Pérez et al.; Sauer et al., 2016a); in brief, the ruminoreticulum was placed on its left side, and the height and length of the rumen and the reticulum, the length of the curvatura omasi were measured with soft measuring tape. After incision and emptying of the stomach compartments, the dimensions of the ostia intraruminale, ruminoreticulare and reticuloomasale were measured by tape; the thickness of the cranial and caudal rumen pillars, and the maximum height of the reticular crests and papillae unguiculiformes were measured with calipers. The lamina omasi were removed and counted according to their order. Terms are used in agreement with the Nomina Anatomica Veterinaria (ICVGAN, 2012). Data are presented as mean \pm SEM.

\section{RESULTS}

The stomach of the dorcas gazelle was composed of the four classic compartments of the ruminants (Fig. 1). The weight of the full stomach complex was $1966 \pm 321.4$ $\mathrm{g}$. The full weight of reticulorumen was $1658 \pm 49.4 \mathrm{~g}$ and the empty weight was $1105 \pm 35.4 \mathrm{~g}$. Lengths of the dorsal and ventral sacs of the rumen were $26.5 \pm 1.0 \mathrm{~cm}$ and 30.8 $\pm 0.4 \mathrm{~cm}$, respectively. The height of the rumen was 30.5 $\pm 3.2 \mathrm{~cm}$. The Saccus caecus caudoventralis was extended more caudally than the saccus caecus caudodorsalis (Fig. 1). The distance between the cardia and the most caudal part of Saccus caecus caudoventralis was $36 \pm 0.5 \mathrm{~cm}$.

The dorsal sac communicated with the ventral sac by the ostium intraruminale, its border was formed by the ruminal pillars, and its diameter was $12 \times 12 \mathrm{~cm}$. The ruminal pillar thickness was $3 \mathrm{~mm}$ for both the cranial and the caudal pillars. The ostium ruminoreticulare measured $7 \times 8 \mathrm{~cm}$ with a perimeter of $16 \mathrm{~cm}$.

The ruminal papillae were distributed unequally in the rumen (Fig. 2), and were larger and more abundant within the atrium and in the two blindsacs. The papillae were absent indorsal part of the dorsal sac. The ruminal pillars had no papillae. The ruminal papillae gradually continued with the cristae reticuli cranially to the plica ruminoreticularis.

The height of the reticulum was $12.2 \pm 2.4 \mathrm{~cm}$ and the craniocaudal length was $12.0 \pm 0.5 \mathrm{~cm}$. The maximum height of the cristae reticuli was $1.1 \mathrm{~cm}$. The cellulae reticuli were divided and contained secondary and tertiary crests (Fig. 2). They were broader and deeper near the greater curvature and were becoming smaller toward the lesser curvature. The maximum length of papillae 
unguiculiformes was $0.25 \mathrm{~cm}$. The ostium reticuloomasale measured $2.5 \pm 0.2 \mathrm{~cm}$.

The weight of full omasum was $84 \pm 8.6 \mathrm{~g}$, and the empty weight was $55.6 \pm 2.6 \mathrm{~g}$. The height of this organ was $7.4 \pm 3.3 \mathrm{~cm}$ and the craniocaudal lenght was $7.3 \pm 0.6$ $\mathrm{cm}$. The curvatura omasi measured $12.1 \pm 0.1 \mathrm{~cm}$. The omasum had 11 primary, 5 secondary, 5 tertiary and 11 quaternary laminae omasi and the sides of the laminae were marked by the presence of the papillae omasi.

The abomasum full weight was $124 \pm 8.3 \mathrm{~g}$, and the empty weight was $82 \pm 4.1 \mathrm{~g}$. The length of the curvature major was $29.5 \pm 0.7 \mathrm{~cm}$ and the length of the curvatura minor was $16.9 \pm 0.3 \mathrm{~cm}$. The abomasum had 17 Plicae spirales abomasi,and the first one close to omaso-abomasal orifice conformed the velo abomasicum, and a small torus pyloricus was present.

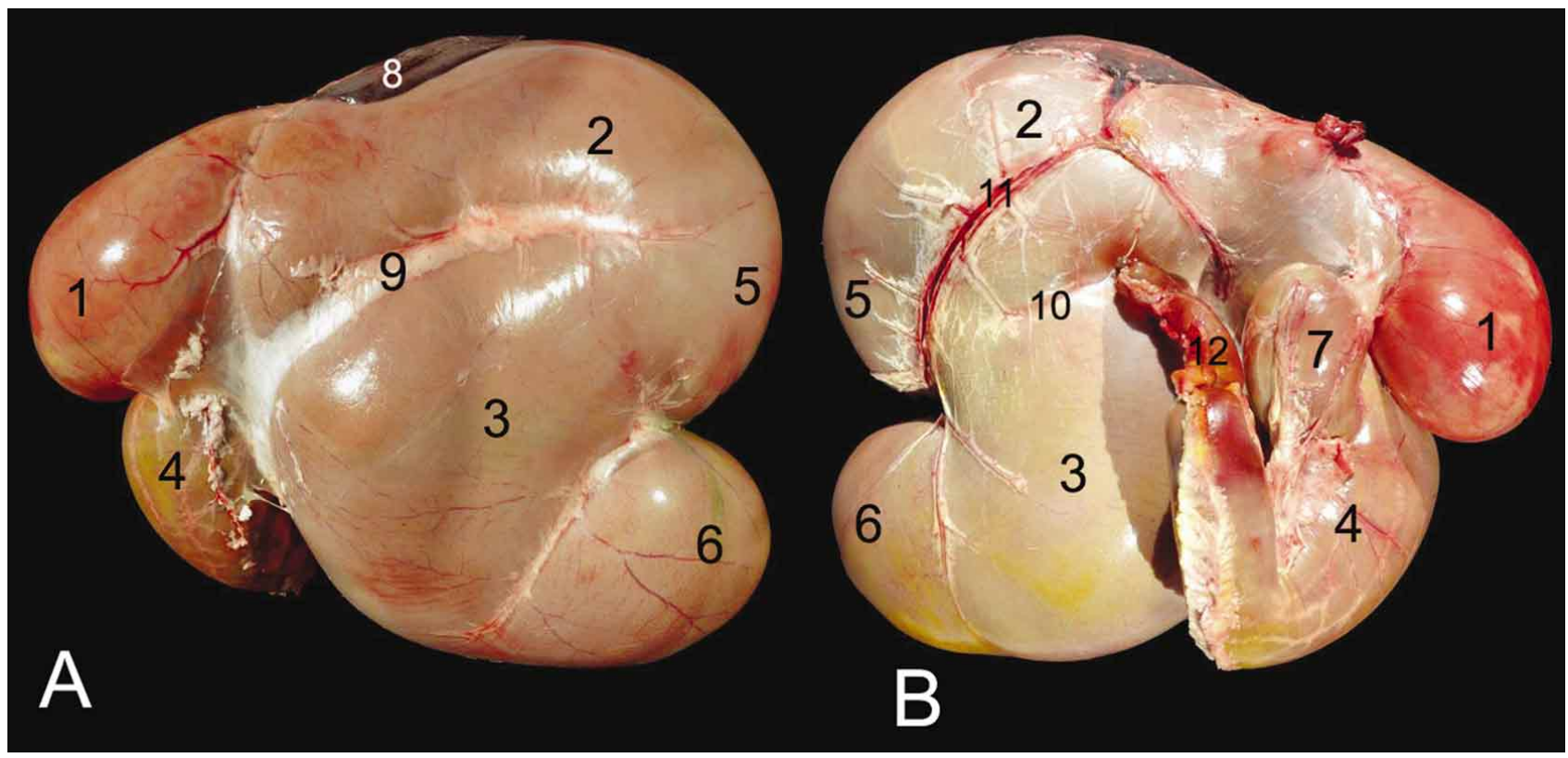

Fig. 1. A: Left view of the Dorcas gazelle (Gazella dorcas) stomach; B: Right view of the dorcas gazelle stomach; 1: Reticulum; 2: Rumen, Saccus dorsalis; 3: Rumen, Saccus ventralis; 4: Abomasum; 5: Rumen, Saccus cecus caudodorsalis; 6: Rumen, Saccus cecus caudoventralis; 7: Omasum; 8: Spleen; 9: Sulcus longitudinalis sinister; 10: Sulcus longitudinalis dexter; 11: Sulcus accesorius dexter; 12: Duodenum.

\section{DISCUSSION}

This is the first anatomical description of the stomach of the dorcas gazelle. An important limitation of this study is the small sample size, and the use of semi-

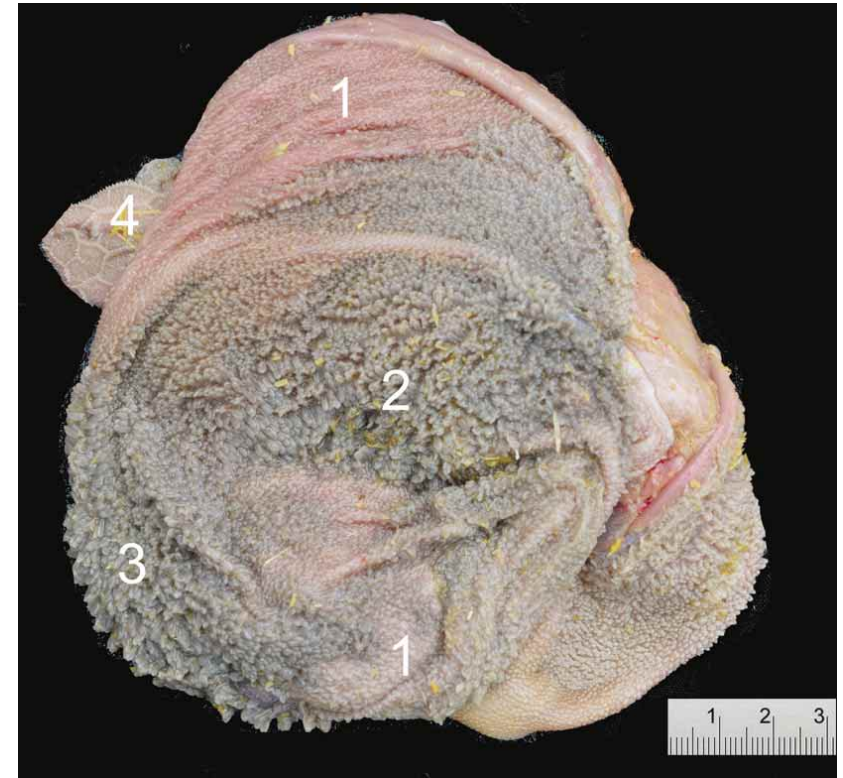

Fig. 2. Inner view of Dorcas gazelle (Gazella dorcas) ruminoreticulum. 1: Rumen, Saccus dorsalis; 2: Rumen, Saccus ventralis; 3: Atrium ruminis ; 4: Reticulum. captive animals to study the anatomy of the stomach, although in this case the diet consisted partly of natural vegetation, the enclosure at Frigya Park was quite large 
and conditions were similar to the natural habitat, with the same trees and plants.

When comparing the results of the dorcas gazelles of this study to those of sand gazelles (Gazella subgutturosa marica) from Sauer et al. (2016b), no consistent pattern is evident. Sand gazelles had higher reticular crests and thicker rumen pillars than the dorcas gazelles. Based on these measurements, the dorcas would appear as a ruminant resembling more a 'browser' than a 'grazer' in the classical categorization (Hofmann, 1973; Hofmann, 1989). Sand gazelles are considered intermediate feeders including an average of around $40 \%$ grass in their diet (reviewed in Dittmann et al.), which could, in this logic, explain more developed reticular crests and rumen pillars when compared to dorcas gazelles with an estimated $25 \%$ grass in their natural diet (Gagnon \& Chew, 2000).

In constrast, the omasum of dorcas gazelles in the present study was larger than that of sand gazelles, which would lead to the opposite conclusion of a higher proportion of grass in their natural diet (Hofmann, 1973;
Langer, 1988; Clauss et al., 2006). The finding of the subdivided reticular crests in dorcas gazelles is also considered typical for grazing ruminants that generally have pronounced secondary, tertiary and even quaternary crests (Hofmann, 1973; Langer, 1988). Finally, the intraruminal papillation pattern of the dorcas gazelles qualitatively resembled those of 'cattle-type' ruminant species (Clauss et al., 2009) that are characterized by a higher proportion of grass in their natural diet than browsers.

The comparison of the dorcas and the sand gazelle thus exemplifies that classifying species on a variety of morphological measurements is not always straight forward, and that an inhomogeneous distribution of feeding differences between closely related species sharing a similar habitat must be expected. Typical differences related to diet are much more evident when comparing a larger number of species that also include representatives of the extreme ends of the spectrum, such as strict browsers and grazers in terms of feeding type, or 'moose-type' and 'cattletype' ruminants in terms of fore stomach physiology.

JERBI, H.; BAYOUDH, M.; CLAUSS, M. \& PÉREZ, W. Anatomía macroscópica del estómago de la gacela dorcas (Gazella Dorcas, Linnaeus, 1758). Int. J. Morphol., 34(4):1266-1270, 2016.

RESUMEN: En este estudio se describe la anatomía macroscópica del estómago de cuatro gacelas dorcas adultas. Se utilizaron cuatro animales adultos, dos machos y dos hembras (Gazella dorcas) del Parque Zoológico Frigya, Enfidha, Túnez. Las papilas ruminales estaban distribuidas de manera desigual en el rumen, y se observaron de mayor tamaño y abundantes dentro de la aurícula, y en ambos saccus cecus. No se observaron papilas en la parte dorsal del saco dorsal. Los reticuli cellulae se dividieron y contenían crestas secundarias y terciarias. La curvatura omasi media 12,1 $\pm 0,1 \mathrm{~cm}$. Una comparación con los datos de la literatura en gacelas de arena (Gazella subgutturosa marica) indica que no se puede esperar un patrón exacto en las especies estrechamente relacionadas que llenan nichos similares, pero no cuentan con una imagen homogénea. En algunas de las mediciones se observa la tendencia hacia un tipo específico de alimentación en una especie, mientras que otras medidas tienden a asociar este tipo de alimentación a otras especies. La morfología del estómago de la gacela dorcas indica que la morfofisiologia de este tipo de ganado es representativa de alimentadores intermedios.

PALABRAS CLAVE: Abomaso; Abdomen; Antílope; Estómago esofágico; Proventrículo.

\section{REFERENCES}

Clauss, M.; Hofmann, R. R.; Hummel, J.; Adamczewski, J.; Nygren, K.; Pitra, C.; Streich, W. J. \& Reese, S. Macroscopic anatomy of the omasum of free-ranging moose (Alces alces) and muskoxen (Ovibos moschatus) and a comparison of the omasal laminal surface area in 34 ruminant species. J. Zool., 270(2):346-58, 2006.

Clauss, M.; Hofmann, R. R.; Fickel, J.; Streich, W. J. \& Hummel, $\mathrm{J}$. The intraruminal papillation gradient in wild ruminants of different feeding types: Implications for rumen physiology. J. Morphol., 270(8):929-42, 2009.
Clauss, M.; Hume, I. D. \& Hummel, J. Evolutionary adaptations of ruminants and their potential relevance for modern production systems. Animal, 4(7):979-92, 2010a.

Clauss, M.; Hofmann, R. R.; Streich, W. J.; Fickel, J. \& Hummel, $\mathrm{J}$. Convergence in the macroscopic anatomy of the reticulum in wild ruminant species of different feeding types and a new resulting hypothesis on reticular function. J. Zool., 281(1):26$38,2010 \mathrm{~b}$.

Codron, D. \& Clauss, M. Rumen physiology constrains diet niche: 
linking digestive physiology and food selection across wild ruminant species. Can. J. Zool., 8(11):1129-38, 2010.

Cuzin, F. Les Grands Mammifères du Maroc Méridional (Haut Atlas, Anti Atlas Et Sahara): Distribution, Écologie et Conservation. PhD Thesis. Montpellier, Université de Montpellier, 2003.

Dittmann, M. T.; Hummel, J.; Hammer, S.; Arif, A.; Hebel, C.; Müller, D. W.; Fritz, J.; Steuer, P.; Schwarm, A.; Kreuzer, M. \& Clauss, M. Digesta kinetics in gazelles in comparison to other ruminants: Evidence for taxon-specific rumen fluid throughput to adjust digesta washing to the natural diet. Comp. Biochem. Physiol. A Mol. Integr. Physiol., 185:58-68, 2015.

Gagnon, M. \& Chew, A. E. Dietary preferences in extant African Bovidae. J. Mammal., 81(2):490-511, 2000.

Ghobrial, L. I. Water relation and requirement of the dorcas gazelle in the Sudan. Mammalia, 38(1):88-107, 1974.

Ghobrial, L. I. Observations on the intake of sea water by the dorcas gazelle. Mammalia, 40(3):489-94, 1976.

Godinho, R.; Abáigar, T.; Lopes, S.; Essalhi, A.; Ouragh, L.; Cano, M. \& Ferrand, N. Conservation genetics of the endangered Dorcas gazelle (Gazella dorcas spp.) in Northwestern Africa. Conserv. Genet., 13(4):1003-15, 2012.

Groves, C. P. Notes on the gazelles. 3. The dorcas gazelles of North Africa. An. Mus. Civ. Stor. Nat. Genova, 83:455-71, 1981.

Hofmann, R. R. \& Stewart, D. R. M. Grazer or browser: A classification based on the stomach-structure and feeding habit of East African ruminants. Mammalia, 36(2):226-40, 1972.

Hofmann, R. R. The Ruminant Stomach: Stomach Structure and Feeding Habits of East African Game Ruminants. Nairobi, East African Literature Bureau, 1973.

Hofmann, R. R. Morphophysiological evolutionary adaptations of the ruminant digestive system. In: Dobson, A. (Ed.). Comparative Aspects of Physiology of Digestion in Ruminants. Ithaca, Cornell University Press, 1988. pp.1-20.

Hofmann, R. R. Evolutionary steps of ecophysiological adaptation and diversification of ruminants: a comparative view of their digestive system. Oecologia, 78(4):443-57, 1989.

Hofmann, R. R.; Knight, M. H. \& Skinner, J. D. On structural characteristics and morphophysiological adaptation of the springbok (Antidorcas marsupialis) digestive system. Trans. $R$. Soc. S. Afr., 50(2):125-42, 1995.

IUCN SSC Antelope Specialist Group. Gazella dorcas. The IUCN Red List of Threatened Species 2008:e.T8969A12941858, 2008. Available from: http://dx.doi.org/10.2305/ IUCN.UK.2008.RLTS.T8969A12941858.en
Lafontaine, R. M.; Beudels-Jamar, R. C.; Devillers, P. \& Wacher, T. Gazella dorcas. In: Beudels-Jamar, R. C.; Devillers, P.; Lafontaine, R. M.; Devillers-Terschuren, J. \& Beudels, M. O. (Eds.). Sahelo-Saharan Antelopes. Status and Perspectives. 2nd ed. Bonn, UNEP/CMS Secretariat, 2006.

Langer, P. Vergleichend anatomische Untersuchungen am Magen der Artiodactyla (Owen, 1848). II. Untersuchungen am Magen der Tylopoda und Ruminantia. Gegenb. Morphol. Jb., 119:633-95, 1973.

Langer, P. The Mammalian Herbivore Stomach: Comparative Anatomy, Function, and Evolution. Stuttgart, Gustav Fischer Verlag, 1988.

Pérez, W. \& Ungerfeld, R. Gross anatomy of the stomach of the pampas deer, Ozotoceros bezoarticus (Artiodactyla: Cervidae). Zoologia (Curitiba), 29(4):337-42, 2012.

Pérez, W.; Erdogan, S. \& Ungerfeld, R. Anatomical study of the gastrointestinal tract in free-living axis deer (Axis axis). Anat. Histol. Embryol., 44(1):43-9, 2015.

Sauer, C.; Bertelsen, M. F.; Lund, P.; Weisbjerg, M. R. \& Clauss, M. Quantitative macroscopic anatomy of the giraffe (Giraffa camelopardalis) digestive tract. Anat. Histol. Embryol., 45(5):338-49, $2016 \mathrm{a}$.

Sauer, C.; Bertelsen, M. F.; Hammer, S.; Lund, P.; Weisbjerg, M. R. \& Clauss, M. Macroscopic digestive tract anatomy of two small antelopes, the blackbuck (Antilope cervicapra) and the Arabian sand gazelle (Gazella subgutturosa marica). Anat. Histol. Embryol., 45(5):392-8, 2016 b.

International Committee on Veterinary Gross Anatomical Nomenclature (ICVGAN). Nomina Anatomica Veterinaria. Hannover, World Association of Veterinary Anatomists, 2012.

Ward, D. \& Saltz, D. Forging at different spatial scales: Dorcas gazelles foraging for lilies in the Negev Desert. Ecology, 75(1):48-58, 1994.

Yom-Tov, Y.; Mendelssohn, H. \& Groves, C. P. Gazella dorcas. Mamm. Species, (491):1-6, 1995.

\section{Correspondence to: \\ William Pérez \\ Área de Anatomía \\ Facultad de Veterinaria \\ Lasplaces 1620, 11600 \\ Montevideo \\ URUGUAY}

Email: vetanat@gmail.com 